\title{
Why the Endemoepidemicity Persistence of Cholera in Moba (DR. of Congo)?: Preliminary Study in the Health Area of Regeza in 2016
}

\author{
Bukasa Héman Kabemba 1,2,3,4*, Augustin Mpo Ntambwe ${ }^{3}$, Sébastien Kashimpo Yamutalua ${ }^{5}$, \\ Kazadi Ntita Prince5, Gaston Alimasi Yuma ${ }^{6}$, Ngoyi Nyongonyi Micheline, \\ Paulin Kabamba Lupueka ${ }^{5}$, Elysée Ngama Ngoyi1,7, Ramazani Selemani1,7, \\ Kaimba Manda Martine ${ }^{1,7}$, Mapengo Mbwili Jean Pierre ${ }^{8}$
}

\footnotetext{
${ }^{1}$ Department of Nursing Sciences, Higher Institute of Medical Techniques of Kalemie, Kalemie, Democratic Republic of Congo ${ }^{2}$ Department of Nursing Sciences, Faculty of Health Sciences, University Institute of Congo, Lubumbashi, Democratic Republic of Congo

${ }^{3}$ Department of Nursing Sciences, Higher Institute of Medical Techniques of Lubao, Lubao, Democratic Republic of Congo ${ }^{4}$ Department of Nursing Sciences, Higher Institute of Medical Techniques of Tshofa, Tshofa, Democratic Republic of Congo ${ }^{5}$ Department of Health Community and Nursing Sciences, Higher Institute of Medical Techniques of Kabinda,

Kabinda, Democratic Republic of Congo

${ }^{6}$ Department of Public Health, Faculty of Medicine, University of Kalemie, Kalemie, Democratic Republic of Congo ${ }^{7}$ Department of Nursing Sciences, Higher Institute of Medical Techniques of Moba, Moba, Democratic Republic of Congo ${ }^{8}$ Department of Nursing Sciences, Institute of Medical Techniques, Monseigneur Dominique Kimpinde, Moba, Democratic Republic of Congo

Email: ^hemanuska@gmail.com
}

How to cite this paper: Kabemba, B.H., Ntambwe, A.M., Yamutalua, S.K., Prince, K.N., Yuma, G.A., Micheline, N.N., Lupueka, P.K., Ngoyi, E.N., Selemani, R., Martine, K.M. and Pierre, M.M.J. (2018) Why the Endemo epidemicity Persistence of Cholera in Moba (DR. of Congo)?: Preliminary Study in the Health Area of Regeza in 2016. Open Access Library Journal, 5: e3500. https://doi.org/10.4236/oalib.1103500

Received: March 6, 2017

Accepted: June 16, 2018

Published: June 19, 2018

Copyright $\odot 2018$ by authors and Open Access Library Inc.

This work is licensed under the Creative Commons Attribution International License (CC BY 4.0).

http://creativecommons.org/licenses/by/4.0/

\begin{abstract}
Background: Cholera is a very old endemo-epidemic disease linked to the conditions of defective hygiene. It is a public health problem, mainly in Africa and Asia. Aim: The purpose of this preliminary study was to determine the level of knowledge of the population in relation to the factors favoring the endemicity and epidemicity of cholera among the exposed populations. Methods: This is a prospective, descriptive cross-sectional and analytical study. Interviewing and document analysis techniques were used in the different strata over the three-month period, from April to June 2016. Results: The profile of the respondents was mostly male (56.7\%) aged over 30 years (61.2\%), farmers $(40.9 \%)$ or fishermen $(26.1 \%)$ with a low level of instruction. The mean age was $32.1 \pm 2.3$ years with extremes ranking from 18 to 57 years. This study revealed that the main factors contributing to endemicity and epidemicity persistence of cholera were the low level of education, the environmental proximity with rivers and Lake Tanganyika, the incorrect habits of the population to think of the mystic in the genesis of cholera cases disease, low
\end{abstract}

\section{Open Access}


level of mobilization for cholera control, poor knowledge of the pathways of transmission of cholera, poor treatment of drinking water and the large consumption of inadequate water, knowledge of the critical moments of handwashing, the low use of soap or ash when washing hands, the large proportion of plots without latrines or with unhygienic latrines, poor management of household waste, poor organization of placement sessions at the level of cholera, poor knowledge of the means available to fight against cholera, poor management of faecal peril and poor general hygiene conditions. Conclusion: The conditions of poor knowledge of cholera and of deficient hygiene combined in our environment are favorable to the endemicity and sometimes the occurrence of cholera epidemics. Efforts should be made in relation to the improvement of hygiene conditions (individual and collective), communication for behavioral change and education of the population in the fight against cholera. The tree of solution to the problems of cholera encountered in this study (in Appendix) may be the model to follow.

\section{Subject Areas}

Epidemiology, Infectious Diseases, Public Health

\section{Keywords}

Cholera, Health, Hygiene, Vibrio cholerae

\section{Introduction}

In developing countries, transmitted infectious diseases are costly to the public and a public health problem [1] [2] [3]. These include those usually expressed by acute diarrhea such as cholera, Escherichia coli infection, Campylobacter jejuni infection, Rotavirus infection, Giardiasis, Intestinal amoebiasis, Salmonellosis, Shigellosis, etc. [4] [5].

Cholera is a very old bacterial infectious disease (1503 by an officer of the explorer Vasco De Gama in Calcutta: the initial focus of the world on the Ganges River in India) and contagious [5] [6]. It is caused by a gram-negative bacillus called Vibrio cholerae (which has the tropism for the epithelium of the small intestine after oral ingestion by food and contaminated water). Clinically, cholera is characterized by colorless, painless, diarrhea and mainly rice form appearance preceding vomiting [2] [3] [4] [5]. Severe dehydration following acute diarrhea leads the victims to death in the absence of treatment.

Cholera is an endemic and epidemic disease linked to defective hygiene conditions, the virulence of the responsible microorganism (Vibrio cholerae) and the capacity of the body to defend itself by the various natural and immune immunological mechanisms [2] [6] [7].

Each year around 1.3 to 4 million cholera cases are reported with 21 miles to 143 thousand deaths worldwide [5] [7] [8]. For the World Health Organization, 
notifications appear to be less in some countries due to a deficit in national surveillance systems and a refusal to alert potential tourists for fear of risk of economic loss [8].

Several cholera epidemics have been recorded worldwide and Africa is more concerned with prevalence and death [6] [8] [9] [10], followed by Asia [11]. Europe and North America would be spared [9] [11]. The reasons seem to be unknown but the world of life and collective hygiene measures in these developed countries can have a great influence on the absence of cholera cases in Europe and North America [5] [6] [10] [11] [12] [13] [14].

The Democratic Republic of the Congo (DRC) was among the five countries representing about eighty-five percent of cases notified with Ghana, Haiti, Nigeria and Afghanistan in 2013 [9]. In DRC, the first cases of cholera were reported in 1975. The most important cholera outbreaks are found in the Lake Provinces of North Kivu, South Kivu, and the former Katanga (including Moba) and along the Congo River where the disease has endemoepidemic cyclical characteristics. In the areas bordering Lake Tanganyika (Moba, Kalemie, Fizi and Uvira) in the DRC, cholera is endemic throughout most of the year with epidemic outbreaks accompanied by deaths, especially during the rainy season. In the context of Moba, several non-governmental organizations have been funded to combat the morbidity and mortality associated with Vibrio cholerae. Despite these financial means, cholera remains a public health problem (especially for health areas along Lake Tanganyika). This endemo-epidemic state of cholera in Moba had prompted us to ask a question: Why is the persistence of cholera in Moba? To answer this question, a preliminary study was first recommended. The objective of this study is to determine the level of knowledge of the population in relation to the factors favoring the endemicity and epidemicity of cholera among the populations exposed. The results of this study will be necessary tools to take into account by any partner involved in the fight against cholera in our province and middle of Moba.

\section{Methods}

\subsection{Site of the Study}

This study was conducted in health area of Regeza (Moba Health Zone and Territory, Tanganyika Provincial Health Division, South-East DRC) (Figure 1). This young health area follows the division of the Moba-Port health area and comprises 11 villages and blocks (Belair block, Kipushi block, Likasi block, Moba block, Tanganyika block, Tsholwe village, Nkondwe village, Mufaume village, Katende village, Kapeso village and Mushende village).

The population of the Regeza Health Area (13,334 inhabitants in 2016) is mainly composed of the Tabwa tribe and the main activities are agriculture and fishing on Lake Tanganyika. The population has a low level of education, which often explains the rarity of university executives. In terms of health, Regeza, Mulunguzi, Kansenge, Liombe, Kizike, Kiku and Moliro health areas are part of 


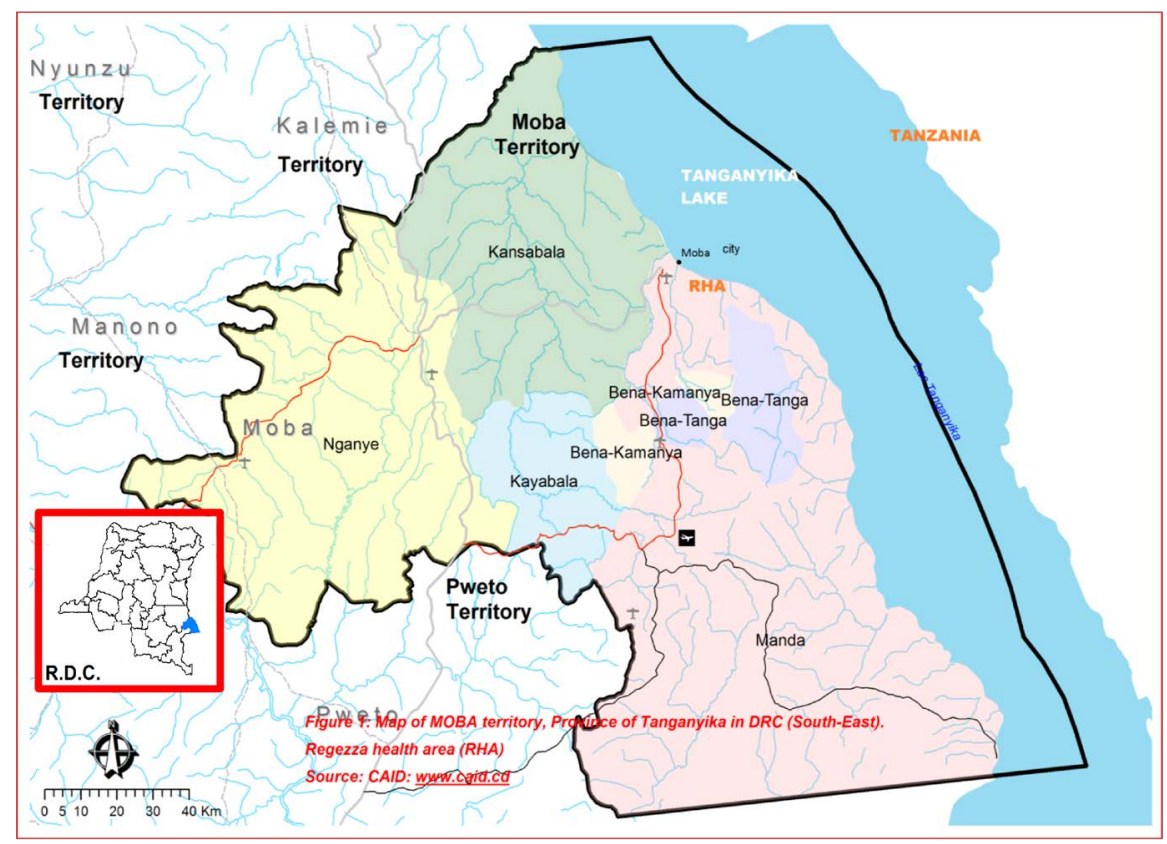

Figure 1. Map of Moba's territory in democratic republic of Congo. There is the Regeza Health Areas (RHA) in Moba, near Tanganyika Lake.

the health areas in the Moba Zone where the cholera is endemic and epidemic. We only meet the nurses. Public health centers and private health Posts are in most cases less equipped. It should be noted that the Moba Health Zone is part of the territory of Moba $\left(24,500 \mathrm{Km}^{2}\right.$ and 609,406 inhabitants in 2016) and has six major diseases: Malaria, acute respiratory infections, simple diarrhea, dysentery (Especially in areas of artisanal mining), measles, cholera and sexually transmitted infections (STIs).

\subsection{Types, Period and Population of Study}

This study was prospective, descriptive cross-sectional and analytical. Interviewing and document analysis techniques were used. The period of our investigation was three months, from April to June 2016. The study population was composed of the inhabitants of the health area of Regeza. The study sample was simple random and calculated using the mathematical below formula of Schwartz. In the absence of the prevalence in the literature that corresponded to our objective, we had considered the prevalence of $50 \%$.

$$
n \geq \frac{Z_{\alpha}^{2} \times p(1-p)}{d^{2}}=\frac{1.96^{2} \times 0.5 \times 0.5}{(0.05)^{2}}=\frac{0.9604}{0.0025} \cong 384
$$

The minimum sample in this study should be 384 . Following the possible $10 \%$ refusal to answer our questions, 39 people to be interviewed had been added. For this study, 430 individuals had been selected. The population of the health area was subdivided into strata. The expected 430 individuals were distributed in the strata (11 in total) according to the welding weight expected in each stratum.

The inclusion criteria was : living in the Regeza Health Area, agreeing to par- 
ticipate in this study, being over 18 years of age and being part of the targeted household, completing the desired variables. Any person did not meet these criteria had been excluded. The parameters studied in this study include the Age, the sex, the educational level, the Occupation, the drinking water (source, preservation and treatment), the handwashing (critical moment, use of soap or ash), the existence of latrines in the plot, the waste management Behavioral change communication in favor of cholera and knowledge of cholera control measures.

\subsection{Statistical Processing and Analysis of Data}

Data collected on survey forms have been processed and analyzed using Excel software (Microsoft, USA, 2010). The results were presented in the form of tables comprising successively the observed numbers, frequencies, means and standard deviation. The unadjusted Pearson Chi-Square test was used to assess the relationship between the variables. The threshold of 0.05 for the alpha error was retained.

\section{Results}

During the period of our survey, 430 individuals had agreed to respond to our interview. 418 people $(97.2 \%)$ were aware of cholera and $2.8 \%(n=12)$ of those interviewed during the study period did not know the existence of cholera. Those persons who knew the existence of cholera were retained as a study population (418).

\subsection{Socio-Demographic Characteristics}

In our study series, individuals over 30 years of age $(n=256$ or $61.2 \%)$ were significantly more likely $(\mathrm{p}<0.05)$. The mean age was $32.1 \pm 2.3$ years with extremes ranging from 18 to 57 years. Men were more likely than female 237 (56.7\%) compared with 181 (43.3\%). The sex-ratio was 1.3 in favor of the male sex (Table 1). According to Table 1, the majority of respondents had a primary education level ( $\mathrm{n}=190$ or $45.5 \%$ ) followed by illiterates $(\mathrm{n}=124$ or $29.6 \%)$ and those at the secondary school level $(\mathrm{n}=102$ or 24.4$)$. Only two respondents had a higher education and university level.

Farmers were the first professions in our study series ( $\mathrm{n}=171$ or $40.9 \%$ ) followed by fishermen $(\mathrm{n}=109$ or $26.1 \%)$, teachers $(\mathrm{n}=56$ or $13.4 \%)$, traders $(\mathrm{n}=$ 45 or $10.8 \%)$. Public officials accounted for 11 people, or $2.6 \%$.

\subsection{Knowledge of the Pathways of Transmission of Cholera and Drinking water Consumed}

During the period of our investigation, dirty hands were cited by 353 respondents (84.4\%) as the main pathways or route of transmission of Vibrio cholerae and consequently the occurrence of cholera cases (Table 2). Contaminated food and water were weakly respectively evoked with $39.0 \%(\mathrm{n}=163)$ and $36.1 \%(\mathrm{n}=$ 151).

Table 3 indicates that the main source of drinking water supply was the River 
Table 1. Socio-demographic characteristics $(n=418)$.

\begin{tabular}{|c|c|}
\hline Socio-demographic characteristics & $\mathrm{n}(\%)$ \\
\hline \multicolumn{2}{|l|}{ Age (Years) } \\
\hline$\leq 30$ & $162(38.8)$ \\
\hline$>30$ & $256(61.2)^{\star}$ \\
\hline \multicolumn{2}{|l|}{ Gender } \\
\hline Male & $237(56.7)$ \\
\hline Female & $181(43.3)$ \\
\hline \multicolumn{2}{|l|}{ Education level (Studies) } \\
\hline Illiterate & $124(29.6)$ \\
\hline Primary & $190(45.5)$ \\
\hline Secondary & $102(24.4)$ \\
\hline High studies and University & $2(0.5)$ \\
\hline \multicolumn{2}{|l|}{ Profession } \\
\hline Farmers & $171(40.9)$ \\
\hline Fishers & $109(26.1)$ \\
\hline Traders & $45(10.8)$ \\
\hline Teachers & $56(13.4)$ \\
\hline Public administration & $11(2.6)$ \\
\hline Others & $26(6.2)$ \\
\hline
\end{tabular}

${ }^{*}$ Significant at $\mathrm{p}<0.05$; Meansage $32.1 \pm 2.3$ years and extremes 18 to 57 years.

Table 2. Knowledge of pathways for transmission of cholera.

\begin{tabular}{ccc}
\hline Pathways for transmission of cholera & $\mathrm{n}$ & $\%$ \\
\hline Hands halls $(\mathrm{n}=418)$ & 353 & 84.4 \\
Contaminated foods $\quad(\mathrm{n}=418)$ & 163 & 39.0 \\
Contaminated water from fecal matter $(\mathrm{n}=418)$ & 151 & 36.1 \\
\hline
\end{tabular}

(Moba River) and Lake Tanganyika ( $\mathrm{n}=211$ or $50.5 \%)$ followed by the wells ( $\mathrm{n}$ $=148$ or $35.4 \%)$, Tap $(n=36$ or $8.6 \%)$ and unmanaged source $(n=23$ or $5.5 \%)$. The proportion of individuals who consume water from the protected wells was higher than that of individuals who consume the water that flows through the tap ("REGIDESO" Company of the DRC) with 137 vs 36 . The cans were cited as the first container ( $\mathrm{n}=198$ or $47.4 \%$ ) followed by Bassins ( $\mathrm{n}=117$ or $28.0 \%$ ), Pitches $(n=70$ or $16.7 \%)$ and Drums $(n=19,4.5 \%)$ (Table 3$)$. It was found after our survey that the majority of respondents did not consume significantly ( $\mathrm{p}<$ 0.05 ) the treated water $(\mathrm{n}=249$ or $59.6 \%)$. Water treatment was carried out for only 169 households (40.4\%): the main means of water treatment was chlorination ( $n=159$ out of 169 , i.e. significantly $94.1 \%$ ), Boiling (ten households or $2.4 \%$ ). 
Table 3. Drinking water consumed by respondents.

\begin{tabular}{|c|c|c|}
\hline Drinking water consumed & $\mathbf{n}$ & $\%$ \\
\hline \multicolumn{3}{|l|}{ Main source of supply $(n=418)$} \\
\hline \multicolumn{3}{|l|}{ Well } \\
\hline Protected & 137 & 32.8 \\
\hline Unprotected & 11 & 2.6 \\
\hline Subtotal & 148 & 35.4 \\
\hline \multicolumn{3}{|l|}{ Source } \\
\hline Furnished & - & - \\
\hline Unfurnished & 23 & 5.5 \\
\hline Subtotal & 23 & 5.5 \\
\hline River and lake (Tanganyika) & 211 & 50.5 \\
\hline Tap water & 36 & 8.6 \\
\hline \multicolumn{3}{|c|}{ Container for home preservation $(n=418)$} \\
\hline Cans/Bottles & 198 & 47.4 \\
\hline Drums & 19 & 4.5 \\
\hline Basins & 117 & 28.0 \\
\hline Pitchers & 70 & 16.7 \\
\hline Large cooking pots & 2 & 0.5 \\
\hline Fridge & 12 & 2.9 \\
\hline \multicolumn{3}{|l|}{ Home treatment of water $(n=418)$} \\
\hline \multicolumn{3}{|l|}{ Yes } \\
\hline Chlorine & 159 & 38.0 \\
\hline Boiling & 10 & 2.4 \\
\hline Sub-total & 169 & 40.4 \\
\hline No & 249 & $59.6^{*}$ \\
\hline
\end{tabular}

${ }^{\star}$ Significant at $\mathrm{p}<0.05$.

\subsection{Hygiene: Handwashing, Existence of Latrines and Management of Household Waste}

Table 4 indicates that the greatest critical time for handwashing was before eating or feeding or nursing the baby $(\mathrm{n}=371,88.8 \%)$. The other critical moments, essential in hand hygiene, were less evoked: before preparing food $(\mathrm{n}=142$ or $34.0 \%$ ), after cleaning or changing clothes in the baby ( $\mathrm{n}=95$ or $22.7 \%$ ), after having groomed ( $\mathrm{n}=135$ or $32.3 \%)$ and after the walk ( $\mathrm{n}=72$ or $17.2 \%)$. In the majority of cases ( $n=288$ or $68.9 \%$ ); handwashing was done without soap or ash $(\mathrm{n}=130$ or $31.1 \%)$. The difference between those using soap and hand washing ash and those who did not have this habit was significant $(\mathrm{p}<0.05)$.

In the majority of the plots visited, latrines $(n=339$ or $81.1 \%)$ were significantly $(\mathrm{p}<0.05)$. However, these latrines were essentially unhygienic 
Table 4. Washing the hands.

\begin{tabular}{ccc}
\hline Hand washing & N & $\%$ \\
\hline Knowledge of Critical Moment $(\mathbf{n}=418)$ & & \\
Before eating or eating or breastfeeding & 371 & 88.8 \\
Before preparing food & 142 & 34.0 \\
After cleaning or changing linen in children & 95 & 22.7 \\
After having been at the toilet & 135 & 32.3 \\
After the walk & 72 & 17.2 \\
Practical use of soap or ash (n= 418) & & \\
Yes & 119 & 28.5 \\
Soap & 11 & 2.6 \\
Ash & 130 & 31.1 \\
Subtotal & 288 & $68.9^{*}$ \\
No & &
\end{tabular}

* Significant at $\mathrm{p}<0.05$.

( $n=285$ or $68.2 \%$ ). Plots without latrines were encountered in 79 cases, or $18.9 \%$ (Table 5).

According to Table 5, household waste was managed in 214 households $(51.2 \%)$ by trash holes $(n=128$ or $30.6 \%)$ and garbage $(n=86$ or $20.6 \%)$. No plot had the incinerator at its disposal. In the majority of cases, the waste was left in the air without burial: 388 households (92.8\%) vs 30 (7.2\%). The difference observed is very significant $(\mathrm{p}<0.05)$.

\subsection{Communication for Behavior Change (CBC) and Cholera Control}

In terms of Table 6, Radio and Churches were mainly listed as the main channels for raising awareness, with respectively $49.3 \%(\mathrm{n}=206)$ and $28.2 \%(\mathrm{n}=$ 118). Community Relay was only mentioned in 33 households (7.9\%). The neighbor's role was recognized as the fourth channel of communication in the fight against cholera ( $\mathrm{n}=30$ or $7.2 \%$ ). DRC Red Cross volunteers (DRCRC) were cited as the only non-governmental organization to mobilize against cholera ( $\mathrm{n}=12$ or $2.9 \%$ ). Cholera exchange visits were only discussed in $54.2 \%$ ( $\mathrm{n}=$ $227)$ and $309(\mathrm{n}=73.9 \%)$ individuals who had never participated in a public cholera information session. The question of knowing how to fight cholera, washing hands at critical times $(n=364$ or $87.1 \%)$ and improving hygiene and sanitation conditions around the home ( $\mathrm{n}=335$ or $80.1 \%$ ) were the main means mentioned. Treatment of drinking water was less cited $(n=195$ or $46.6 \%)$. For 111 individuals or $26.5 \%$, it was necessary to go to the treatment center of cholera (CTC) in case of suspected diarrhea. The means of control were not known in 44 households questioned (10.5\%). 
Table 5. Existence of latrines in the plot and waste management.

\begin{tabular}{ccc}
\hline Latrines and waste & $\mathbf{n}$ & $\%$ \\
\hline Existence of latrines $(\mathbf{n}=418)$ & 339 & 81.1 \\
Yes & 54 & 12.9 \\
Hygienic & 285 & $68.2^{*}$ \\
Unhygienic & 79 & 18.9 \\
No & & \\
Waste management $(\mathbf{n}=418)$ & 214 & 51.2 \\
Yes & 86 & 20.6 \\
Dustbin & 128 & 30.6 \\
Recycle hole & 204 & 48.8 \\
No & & \\
Waste burial $(\mathrm{n}=418)$ & 388 & $92.8^{*}$ \\
No & 30 & 7.2 \\
Yes & & \\
\hline
\end{tabular}

${ }^{*}$ Significant at $\mathrm{p}<0.05$.

Table 6. Communication for behavior change and cholera control.

\begin{tabular}{|c|c|c|}
\hline Communication for behavioral change and cholera control & $\mathrm{n}$ & $\%$ \\
\hline \multicolumn{3}{|l|}{ Awareness Channel $(n=418)$} \\
\hline Radio & 206 & 49.3 \\
\hline Television ${ }^{*}$ & 19 & 4.6 \\
\hline Community Relay & 33 & 7.9 \\
\hline Neighbor & 30 & 7.2 \\
\hline NGOs (DRCRC) & 12 & 2.9 \\
\hline Church & 118 & 28.2 \\
\hline \multicolumn{3}{|l|}{ Visit or visitation for exchange on cholera $(n=418)$} \\
\hline Yes & 227 & 54.3 \\
\hline No & 191 & 45.7 \\
\hline \multicolumn{3}{|l|}{ Participation in the cholera information session $(n=418)$} \\
\hline Yes & 109 & 26.1 \\
\hline No & 309 & $73.9^{* *}$ \\
\hline \multicolumn{3}{|l|}{ Means or ways of control } \\
\hline Wash hands at critical times $(\mathrm{n}=418)$ & 364 & 87.1 \\
\hline Treatment of drinking water $(n=418)$ & 195 & 46.6 \\
\hline Improved hygiene and peri-residential conditions $(n=418)$ & 335 & 80.1 \\
\hline Going to the CTC in case of suspected diarrhea $(n=418)$ & 111 & 26.5 \\
\hline Does not know $(n=418)$ & 44 & 10.5 \\
\hline
\end{tabular}

${ }^{*}$ International and national chains; ${ }^{*}$ Significant at $\mathrm{p}<0.05$; CTC: Cholera Treatment Center; NGOs: Non-Governmental Organization; DRCRC: Red Cross of the DRC. 


\section{Discussion}

Vibrio cholerae colonizes the epithelium of the small intestine and produces a toxic toxin for enterocytes [4] [9]. The infected individual presents several symptoms including vomiting, fever, hypotension, muscle spasms and diarrhea. The greatest complication is dehydration with life-threatening risk following acute diarrhea [5] [6] [7] [12] [15] [16]. Cholera is the preferred companion of natural disasters, situations of conflicts with massive displacements of population and precarious hygiene [16]-[22]. Africa is the continent most affected by the cases notified to WHO [23].

Among the most affected countries is the Democratic Republic of Congo, where Moba is one of the places where cholera is endemic with epidemics in some places [9].

Our work consisted in highlighting the factors favoring this endemicity in order to contribute to the improvement of cholera control. In view of the results of interviewees, conditions are favorable for the occurrence and perpetuation of cholera in our environment. Indeed, while the majority of the population (97.2\%) recognized the existence of cholera (which can be considered a good indicator of community awareness), knowledge about risk factors and control is disappointing.

The notion of factors favoring cholera has been mentioned by several authors, unanimous on the risk of triggering the cholera epidemic in case of deficient hygiene [3]-[10]. The World Health Organization, WHO in its acronym, is constantly encouraging member countries to see closely the various elements incriminated in the genesis of cholera [8].

As regards this series of studies, as found by several authors [3]-[17] [22], the main factors that could be evoked in this preliminary work would be, notwithstanding some positive points: low level of education, proximity with the rivers and Tanganyika Lake, the incorrect habits of the population to think of the mystic in the genesis of cholera, the low level of mobilization in favor of the fight against cholera, the poor knowledge on the means of transmission of cholera, poor drinking water treatment and inadequate water consumption, poor knowledge of critical handwashing times, low use of soap or ash when handwashing, large proportion of plots without latrines, poor management of household waste, poor organization of cholera upgrading sessions, poor knowledge of the available means to fight cholera, poor management of fecal peril and poor hygiene. In several studies, the absence of hygiene measures in relation to drinking water and food has been cited as one of the major elements in the occurrence and sustainability of a cholera epidemic [3] [8] [13]-[19] [22] [23].

Water is an essentially reputed element in the cycle of cholera transmission. A significant proportion of the population consumes water that is unsuitable, poorly preserved and untreated, despite the various mobilizations in the health area: $50.5 \%$ consume mainly river and lake water, $2.6 \%$ for water from unprotected wells and only $40.4 \%$ consume treated water; $47.4 \%$ conserve drinking water in cans/big bottles and $28.0 \%$ in basins. Chlorination was mainly the 
Table 7. (a) Problems and preliminary solutions with cholera in the health area of Regeza: factors favoring cholera endemicity: trees of problem; (b) Problems and preliminary solutions with cholera in the health area of Regezza: factors favoring cholera endemicity: trees of solutions.

(a)

\begin{tabular}{|c|c|c|}
\hline ROOTS = CAUSES & TRONC $=$ CONNECTED & BRANCHES $=$ CONSEQUENCES \\
\hline $\begin{array}{l}\text { 1) Insufficiency of structure for water } \\
\text { supply. }\end{array}$ & & $\begin{array}{l}\text { 1) River water supply, lake (Waterborne diseases: } \\
\text { diarrhea, dysentery, cholera). }\end{array}$ \\
\hline 2) Poor management of water and waste. & - Inaccessibility to drinking safe water. & 2) Sustainability of water-borne diseases. \\
\hline 3) Health Regeza center without C.T.C. & - Lack of hygiene. & 3) A CTC is established in Regezza. \\
\hline 4) Presence of backwaters. & - Low level of education. & 4) Maintenance of potential reservoirs (natural or \\
\hline 5) Insufficient Garbage Holes. & - Poverty. & human). \\
\hline $\begin{array}{l}\text { 6) Polluted water, hand washing In } \\
\text { common after burials. } \\
\text { 7) Latrines broken annually by Floods. }\end{array}$ & - Lack of adequate information. & $\begin{array}{l}\text { 5) Unhealthy with risk of contagion or contamination. } \\
\text { 6) Dissemination and direct spreading of microbes, } \\
\text { including pathogenic cholera germs. }\end{array}$ \\
\hline
\end{tabular}

(b)

\begin{tabular}{|c|c|c|}
\hline RACINES = SPECIFIC OBJECTIVES & TRONC = STRATEGIES & BRANCHES = ACTIVITIES \\
\hline To supply the health area with drinking water. & $\begin{array}{l}\text { Water supply by REGIDESO; } \\
\text { Identify the water sources to be developed } \\
\text { and make them operational. }\end{array}$ & $\begin{array}{l}\text { Advocacy with REGIDESO Managers } \\
\text { for at least } 10 \text { wells in proportion to the } \\
\text { density of the population. }\end{array}$ \\
\hline Properly impede drinking water; & Digging of garbage holes & Raise public awareness of the consequences \\
\hline Reject garbage properly. & Incineration system. & of unhealthy households. \\
\hline Provide Regeza health centre with a C.T.C. & Consolidate a reference structure. & Advocacy at the head health zone. \\
\hline $\begin{array}{l}\text { Destroy or clog all artificial backwaters from } \\
\text { manufacturing bricks. }\end{array}$ & $\begin{array}{l}\text { Impose brick manufacturing outside the } \\
\text { villages. }\end{array}$ & $\begin{array}{l}\text { Activate the administrative organization } \\
\text { (head of territory and the hygiene unit in } \\
\text { Moba). }\end{array}$ \\
\hline Impose garbage holes in each household. & $\begin{array}{l}\text { Take sanctions against the head of } \\
\text { household re-offending. }\end{array}$ & $\begin{array}{l}\text { Involvement of the Head of the territory } \\
\text { and the hygiene unit in Moba. }\end{array}$ \\
\hline $\begin{array}{l}\text { Raise community awareness of environmental } \\
\text { health. }\end{array}$ & $\begin{array}{l}\text { Demonstrate the importance of prevention } \\
\text { against waterborne diseases. }\end{array}$ & Door to door sensitization. \\
\hline
\end{tabular}

technique used and is usually carried out by agents of the Red Cross of the DRC, voluntarily posted to around Lake Tanganyika and rivers to add chlorine diluted in pulsed water. The use of cans to conserve drinking water is being extended to the DRC [24] and is the main alternative due to lack of financial resources.

The low consumption of tap water in this study $(8.6 \%)$ is on the one hand related to the smallest extent of the distribution network of the "REGIDESO" (State Water Supply Company) and other irregularity in the distribution of water. The proximity to the lake and the consumption of its waters was mentioned in Kenyan [6]. Table 4 indicated that $68.9 \%$ of the population did not use soap or ash when washing hands, and knowledge of critical handwashing times was low. Handwashing is a determining factor in the circulation of germs during greetings [21] [22]. Hence, the use of soap should be recommended in order to combat the risk of contamination by the germs of dirty hand diseases.

During our investigation, the hygiene measures were not predominantly good according to the answers of the interviewees. Parts of the population (18.9\%) lack latrines and among those who have it $68.2 \%$ are unhygienic. Waste management is not as satisfactory and landfill is only very low at $7.2 \%$ compared to 
92.8\%. The difference observed is statistically significant after resorting to the law of homogeneous distribution.

The various aforementioned arguments make it possible to perpetuate the endemicity of cholera and the episodic epidemic in our region, as also some authors [2] [5] [6].

Finally, awareness-raising channels should be improved because it is from them that good, appropriate information can reach the population. No channel reaches 50\% in respondents' responses, although radio and church cover $49.3 \%$ and $28.2 \%$ specifically. Access to cholera information is not available for $73.9 \%$ of respondents and there are also several gaps in the control of cholera control (Table 6). The mobilization and information of the population in the fight against waterborne diseases and dirty hands are therefore necessary as pillars in the fight against cholera. It is said that "ignorance kills".

The various elements listed above would explain why cholera is endemic in our environment, especially in the rainy seasons where fecal waste can easily contaminate drinking water. It is important to control them and adopt firm measures to reduce significantly the impact of these risk factors and remove Moba from the list of endemic areas of cholera according to problem trees and solution (see below) mentioned in this study.

The results of this preliminary study demonstrate our willingness to understand why cholera persists cyclically in our environment. Future studies could address the factors that determine the sustainability of cholera on a larger, multicenter sample and generalize the results to the region as a whole.

\section{Conclusion}

The conditions of poor knowledge of cholera and of deficient hygiene combined in our environment are favorable to the endemicity and the occurrence of cholera epidemics in our environment. In this study, low levels of education, environmental proximity to rivers and lakes, ignorance about ways or means of contamination and prevention of cholera, poor mobilization, improper water use, poor hygiene in terms of fecal peril and handwashing, limited access to quality information in place of fear and panic are favorable to endemo-epidemic persistence of cholera in the Regeza Health Area. To some extent, with limitations, these arguments can be applied in all the health areas around Lake Tanganyika. Efforts should be made in relation to the improvement of hygiene conditions (individual and collective), communication for behavioral change and education of the population in the fight against cholera. The solution tree (Table 7(a) and Table $7(\mathrm{~b})$ ) contained in this study may be the model to follow.

\section{Conflict of Interest}

The authors do not report any conflicts of interest in this study.

\section{Acknowledgements}

The authors would like to thank the volunteers of the Red Cross of the DRC for 
the sacrifices in the fight against cholera: a mixture of chlorine in the water that the population draws from the waters of Lake Tanganyika. Also, we would like to thank Saleh Mwemedi and Kibwile Lubeleyi Jean Pierre for their help in data collects.

\section{References}

[1] Harris, J.B., La Rocque, R.C., Charles, R.C., Mazumder, R.N., Khan, A.I. and Bardhan, P.K. (2010) Cholera's Western Front. The Lancet, 376, 1961-1965. https://doi.org/10.1016/S0140-6736(10)62172-1

[2] Orish, V.N. (2015) Economic Burden of Infectious Diseases and Benefit of Control and Prevention in Sub-Saharan Africa. Open Access Library Journal, 2, e2138. https://doi.org/10.4236/oalib.1102138

[3] Traore, O.M. (2008) Epidemiological Aspects of Cholera in the Kayes Health District (Kayes Region): June to December 2005 [Aspects épidémiologiques du choléra dans le district sanitaire de Kayes (Région de Kayes): De juin à décembre 2005]. Thèse médecine FMPOS, Université de Bamako, Bamako, 21-46.

[4] Jameel, S.K., Shafek, M.A., Abdulmohsen, A.M., Mohamed, N.S., Naji, S.R. and Mohammed, T.T. (2016) The Isolation of Vibrio choler and Other Enteric Bacteria with Molecular Characterization of Vibrio cholera during the Outbreak of Baghdad/Iraq in 2015. Advances in Microbiology, 6, 699-715.

https://doi.org/10.4236/aim.2016.69069

[5] Kumar, M. and Sharma, V.L. (2014) Outbreak Investigation of Cholera in a Slum of Northern India. Open Journal of Epidemiology, 4, 243-247.

https://doi.org/10.4236/ojepi.2014.44031

[6] Shapiro, R.L., Otieno, M.R., Adcock, P.M., Phillips-Howard, P.A., Hawley, W.A., et al. (1999) Transmission of epidemic Vibrio cholerae O1 in Rural Western Kenya Associated with Drinking Water from Lake Victoria: An Environmental Reservoir for Cholera? The American Journal of Tropical Medicine Hygiene, 60, 271-276. https://doi.org/10.4269/ajtmh.1999.60.271

[7] Chen, Y.-T., Tang, H.-J., Chao, C.-M. and Lai, C.-C. (2015) Clinical Manifestations of Non-O1 Vibrio cholerae Infections. PLOS ONE, 10, e0116904. https://doi.org/10.1371/journal.pone.0116904

[8] Taylor, D.L., Kahawita, T.M., Cairncross, S. and Ensink, J.H.J. (2015) The Impact of Water, Sanitation and Hygiene Interventions to Control Cholera: A Systematic Review. PLoS ONE, 10, e0135676. https://doi.org/10.1371/journal.pone.0135676

[9] OMS (2016) Cholera, Aide-mémoire $\mathrm{N}^{0}$. http://www.who.int/fr/news-room/fact-sheets/detail/cholera

[10] Aubry, P. and Gauzere, B.-A. (2015) Cholera: Actualités 2015, Médicine Tropicale-Diplôme de Médecine tropicale des pays de l'océan Indien. 1-7 October 2015.

[11] Mamady, K. and Mafoule, S. (2014) Cholera in Guinea: The Implication for Safe Water Sources and Sanitations. Open Journal of Preventive Medicine, 4, 535-544. https://doi.org/10.4236/ojpm.2014.47064

[12] Constantin de Magny, G., Thiaw, W., Kumar, V., Manga, N.M., Diop, B.M., et al. (2012) Cholera Outbreak in Senegal in 2005: Was Climate a Factor? PLoS ONE, 7, e44577. https://doi.org/10.1371/journal.pone.0044577

[13] Tran, N.-T., Taylor, R., Antierens, A. and Staderinim, N. (2015) Cholera in Pregnancy: A Systematic Review and Meta-Analysis of Fetal, Neonatal, and Maternal 
Mortality. PLoS ONE, 10, e0132920.

https://doi.org/10.1371/journal.pone.0132920

[14] Liu, L., Johnson, H.L., Cousens, S., Perin, J., Scott, S., Lawn, J.E., et al. (2012) Global, Regional, and National Causes of Child Mortality: An Updated Systematic Analysis for 2010 with Time Trends since 2000. The Lancet, 379, 2151-2161. https://doi.org/10.1016/S0140-6736(12)60560-1

[15] Ngaha, K.L. (2015) Epidemiological Aspects of Cholera in Mali: About 913 Cases Recorded in the Region of Ségou, Koulikoro, Mopti from 14 August to 30 November 2003 [Aspects épidémiologiques du choléra au Mali: A propos de 913 cas enregistres dans la région de Ségou, Koulikoro, Mopti du 14 Août au 30 novembre 2003]. Thèse de Médecine, FMPOS, Université de Bamako, Bamako, 46-62.

[16] PIarroux, R. (2002) Cholera: Epidemiology and Transmission, an Experience Drawn from Several Humanitarian Interventions in Central Africa, the Indian Ocean and the Central American [Le choléra: Epidémiologie et transmission, expérience tirée de plusieurs interventions humanitaires réalisées en Afrique centrale, dans l'océan indien et en Américain centrale]. Bulletin de la Sociétéde Pathologie Exotique, 95, 345-350.

[17] Mitze, D., Podovic, T. and Blako, P.A. (1994) Vibrio cholerae and Cholera: Molecular to Global Perspective. American Society for Microbiology, Washington DC, 57-63.

[18] Check Abdoula, N., Cruance, L., Aubry, P., Simon. B. and Gauzene, B.-A. (2010) Cholera Outbreak in the Comoros in 2007: A New Approach to Compensation [Epidémie de choléra de 2007 aux Comores: Un nouveau pas vers l'indemnisation]. Médecine Tropicale, 70, 307-308.

[19] Rakot Alison, A.O., Dromigny, J.A., Pister, P. and Mauriciere, P. (2001) Vibrio cholera in Madagascar: Study of a Multi-Resistance Strain [Vibrio cholera à Madagascar: Etude d'une souche multi résistance]. Archives de PInstitut Pasteur Madagascar, 67, 6-13.

[20] Ndour, C.T., Manga, N.M., Ka, R., Diabadiane, N.M., Fortez, L., Seydi, M., et al. (2006) The 2004 Cholera Epidemic in Dakar: Epidemiological, Clinical and Therapeutic Aspects [L'épidémie de choléra de 2004 à Dakar: Aspects épidémiologique, clinique et thérapeutique]. Médecine Tropicale, 66, 33-38.

[21] Derraji, S., Mouketou Mahila, J., Baite, A. and Cherrah, Y. (2013) Observance of Hand Hygiene [L'observance de l'hygiène des mains]. Maroc Médical, 35, 286-290.

[22] Fleming, C.A., Caron, D., Gunn, J.E., Horine, M.S., Matyas, B.T. and Barry, M.A. (2000) An Outbreak of Shigella sonnei Associated with a Recreational Spray Fountain. American Journal of Public Health, 90, 1641-1642. https://doi.org/10.2105/AJPH.90.10.1641

[23] Deen, J.L., Von Seidlein, L., Sur, D., Agtini, M., Lucas, M.E.S., Lopez, A.L., et al. (2008) The High Burden of Cholera in Children: Comparison of Incidence from Endemic Areas in Asia and Africa. PLoS Neglected Tropical Diseases, 2, e173. https://doi.org/10.1371/journal.pntd.0000173

[24] Ngoy, K.C., Kasongo, M.J., Kalonji, L.R., Atiya, M.C., Buntu, K.B. and Monga, B.B. (2015) Gestion d'eau dans les ménages de la cité de Kamina (Cas de l'aire de santé quartier 52). Annales de $P$ Université de Kamina, 14, 41-54. 